\title{
WORKS OF THE CAMDEN SOCIETY.
}

For the Subscription of 1838.9.

1. Restoration of King Edward IV.

2. Kyng Johan, by Bishop Bale.

3. Deposition of King Richard II.

4. Plumpton Correspondence.

5. Anecdotes and Traditions.

$$
\text { For 1839-40. }
$$

6. Political Songs.

7. Hayward's Annals of Elizabeth.

8. Ecclesiastical Documents.

9. Norden's Description of Essex.

10. Warkworth's Chronicle.

11. Kemp's Nine Daies Wonder.

$$
\text { For 1840-41. }
$$

12. The Egerton Papers.

13. Chronica Jocelini de Brakelonda.

14. Irish Narratives, 1641 and 1690.

15. Rishanger's Chronicle.

$$
\text { For 1841-42. }
$$

16. Poems of Walter Mapes.

17. Travels of Nicander Nucius.

18. Three Metrical Romances.

19. Diary of Dr. John Dee.

$$
\text { For 1842-43. }
$$

20. Apology for the Lollards.

21. Rutland Papers.

22. Diary of Bishop Cartwright.

23. Letters of Eminent Literary Men.

24. Proceedings against Alice Kyteler.

$$
\text { For 1843-44. }
$$

25. Promptorium Parvulorum: Tom. I. 26. Suppression of the Monasteries.

27. Leycester Correspondence.

$$
\text { For 1844-45. }
$$

28. French Chronicle of London.

29. Polydore Vergil.

30. The Thornton Romances.

31. Verney's Notes of Long Parliament.
For 1845-46.

32. Autobiography of Sir J. Bramston.

33. Correspondence of Duke of Perth.

34. Liber de Antiquis Legibus.

35. The Chronicle of Calais.

$$
\text { For 1846-47. }
$$

36. Polydore Vergil's History, Vol. I.

37. Italian Relation of England.

38. Church of Middleham.

39. The Camden Miscellany, Vol. I.

$$
\text { For 1847-48. }
$$

40. Life of Lord Grey of Wilton.

41. Diary of Walter Yonge, Esq.

42. Diary of Henry Machyn.

$$
\text { For 1848-49. }
$$

43. Visitation of Huntingdonshire.

44. Obituary of Richard Smyth.

45. Twysden on Government of England.

For 1849-50.

46. Letters of Elizabeth and James VI.

47. Chronicon Petroburgense.

48. Queen Jane and Queen Mary.

For 1850-51.

49. Bury Wills and Inventories.

50. Mapes de Nugis Curialium.

51. Pilgrimage of Sir R. Guylford.

$$
\text { For 1851-52. }
$$

52. Secret Services of Chas. II. \& Jas.II. 53. Chronicle of Grey Friars of London. 54. Promptorium Parvulorum, Tom. II.

$$
\text { For 1852-53. }
$$

55. The Camden Miscellany, Vol. II.

56. Verney Papers to 1639 .

57. The Ancren Riwle.

For 1853-54.

58. Letters of Lady B. Harley.

59. Roll of Bishop Swinfield, Vol. I, 
For 1854-55.

60. Grants, \&c. of Edward the Fifth. 61. The Camden Miscellany, Vol. III. 62. Roll of Bishop Swinfield, Vol. II.

$$
\text { For 1855-56. }
$$

63. Charles I. in 1646 .

64. English Chronicle 1377 to 1461 .

65. The Hospitallers in England.

$$
\text { For 1856-57. }
$$

66 Diary of John Rous.

67. The Trevelyan Papers.

68. Journal of Dean Davies.

For 1857-58.

69. The Domesday of St. Paul's.

70. Liber Famelicus of Sir J.Whitelocke.

$$
\text { For 1858-59. }
$$

71. Savile Correspondence.

72. Blonde of Oxford.

73. The Camden Miscellany, Vol. IV.

$$
\text { For 1859-60. }
$$

74. Diary of Richard Symonds.

75. Papers relating to Milton.

76. Letters of George Lord Carew.

$$
\text { For 1860-61. }
$$

77. Narratives of the Reformation.

78. Correspondence of James VI. with" Srr Robert Cecil.
For 1861-62.

79. Chamberlain's Letters temp. Eliz.

80. Proceedings in Kent 1640.

81. Parliamentary Debates 1610.

For 1862-63.

82. Foreigners Resident in England 1618-1688.

83. Wills from Doctors' Commons.

84. Trevelyan Papers, Part II. to 1643.

\section{For 1863-64.}

85. Life of Marmaduke Rawdon of York.

86. Letters of Margaret of Anjou, \&c.

87. The Camden Miscellany, Vol. V.

$$
\text { For 1864-65. }
$$

88. Letters of Sir Robert Cecil to Sir George Carew.

89 Promptorium Parvulorum; Tom. III.

For 1865-66.

90. Relations between England and Germany.

91. Registrum Prioratus B. M. Wigorniensis.

To Members of the Society, i. e. Subscribers for the current year, applying whilst the Works of former years remain in stock, they will be supplied on the following terms:-

The books for each year, except the two first (which are partly out of print) and the two last, at Ten Shittings.

The books for 1864-65 and 1865-66 (together), for Thirty Shillings.

The subscription of One Pound is due in advance on the 1st of May in every Year. No Books are delivered until the Subscription for the Year has been paid.

W. J. Tномs, Secretary.

A Descriptive Catalogue of the Works of the Society, accompanied by a classified Arrangement of therr Contents, and an Index of Subjects, Authois, and Editors, by Jorn Govar NicBous, F.S.A. is published, bound uniformly with the Series, price Five Shillings.

25 Parlament Street, Westminster. May 1, 1866. 


\section{REPORT OF THE COUNCIL \\ OF \\ THE CAMDEN SOCIETY, \\ ELECTED 2nd OF MAY, 1865.}

The Council of the Camden Society, elected on the 2nd May 1865, refer to the Report of the Auditors for evidence of the satisfactory state of the Society's finances. Nothing is wanting to the prosperity of the Society but such an increase of Members as would counterbalance the loss by death which the Council has annually to deplore. On the present occasion we have to record the deaths of the following Members, some of them among the most distinguished Members of the Society :-

The Venble. Archdeacon Bartholomew.

Charles Henry Cooper, Esq, F.S.A.

G. Stevenson Ellis, Esq.

William Hopkinson, Esq., F.S.A.

The Rev. Samuel Roffey Maitland, D.D., F.R.S., F.S.A.

Rev. James Morton, B.D.

T. C. Neale, Esq.

J. Innes Pocock, EsQ.

J. P. Pollard, Esq.

Honble. T. E. Spring Rice.

Andrew Spottiswoode, Esq.

Joseph Francis Tempest, Esq., F.S.A.

The Rev. W. WheWeLl, D.D., F.R.S., F.S.A., Master of Trinity College, Cambridge.

The Council have, during the past year, added the following Works to the List of suggested Publications :-

Diary of Lady Halkett, Lady of the Bedchamber to Queen Henrietta Maria, from the original MS. in the possession of Johnston Stuart, Esq. To be edited by William J. Thoms, Esq., F.S.A.

Further Collections for the Scriptorum Illustrium Majoris Britanniæ Catalogus, by BISHOP BALE, from the original MS. in the Bodleian Library. 
Letters and other Documents illustrating the Relations between England and Germany at the commencement of the Thirty Years' War. Edited by SAMUEL Rawson Gardiner, Esq. late Student of Christchurch.

The last-mentioned Work has just been issued to the Members, and, it is believed, will be found to contain much valuable illustration of the Foreign Policy of James the First.

Another Work of great learning and importance, which has occupied its Editor, the Venerable Archdeacon Hale, for a considerable time, has also been completed, and will be issued to the Members almost immediately. It is

A Register of the Priory of St. Mary, Worcester, containing an Account of the Lands and Possessions of the Church in the early part of the Thirteenth Century.

This work deals largely with the early condition of the Church in this country, and may be considered a valuable and fitting companion to The Domesday of St. Paul's.

Since the last Annual Meeting the third and concluding portion of $\mathbf{M r}$. Way's edition of The Promptorium Parvulorum has been issued to the Members. The Council, recognising the vast amount of time and labour which Mr. Way has bestowed upon this important contribution to the history both of our language and of our social progress, and anticipating that the volume would be eagerly sought for by scholars who are not Members of the Camden Society, have arranged for the sale of some complete sets of this work at the price of one guinea each; any Member of the Society being entitled to purchase the same at 158. per copy.

The Council of the Early English Text Society having during the past year determined, in conjunction with the Philological Society, to publish a series of Early English and Latin Dictionaries, invited the Camden Society to co-operate with them. The Council of the Camden Society did not feel justified in binding themselves to take part in the whole series of works proposed for publication by the Early English Text Society; but they have arranged with that Society to take copies of-

1. Manipulus Vocabulorum. A Dictionarie of English and Latin Wordes, set forth in suche order as none heretofore hath ben necessary, not onely for scholers-. but also for such as use to write in English Meetre. By P. Levins. London, 1570, of which only two copies are known; and

.2. The Cathoticon. From the unpublished MS. in the possession of Lord Monson, 
a work which is understood to be of equal, if not of greater, interest than The Promptorium.

The Council trust that this arrangement, calculated to be beneficial to the members of all the Societies concerned in it, will be approved by the Members of the Camden Society.

The Council cannot conclude this Report without once more bringing under the notice of the Society the question of literary research at the Court of Probate and the District Registries.

Shortly after the last General Meeting the following Letter was addressed by Sir James Wilde to the Society of Antiquaries and by that Society communicated to the Camden.

"Court of Probate, Westminster, "May 24, 1865.

"SrR,

"I am directed by the Judge of the Court of Probate to acknowledge the receipt of your letter of the 2 lst March, and to state that, although the subject had been previously investigated by him, he again called for a report from the Principal Registrar upon the possibility of allowing Wills of literary interest to be photographed, consistently with their safe custody, for which he is responsible. The Registrar says: - With respect to photographing Wills possessing historical interest, I have little to remark. It cannot be done satisfactorily on the premises belonging to the Court of Probate, and therefore entails the necessity of one of the Record Keepers attending elsewhere, as an original will cannot be intrusted under such circumstances to a junior clerk. Were these attendances of the Record Keepers to be much increased, we should be obliged to apply for a third Record Keeper, and, to prevent this, I think a higher fee should be charged than at present, so as to eusure that no application be made to photograph a will withous some good reason; and he goes on to suggest a fee of $5 l .5 s$. The Judge does not feel at liberty to adopt this suggestion of an extra and unauthorised fee, but he is now in communication with the Treasury on the whole subject of literary inquiries, with the view of rendering the valuable records now scattered over the country in the District Registries available to literary research by being brought together in London, with proper accommodation and a due staff of clerks for their safe custody; and, if the facilities he desires are accorded by the Treasury, he wishes, as part of that scheme, to obtain the means of permitting photographs to be taken. I am desired to inclose a copy of a report furnished by the Chief Registrar on this subject.

"I have the honour to be, "Sir, "Your most obedient Servant, (Signed) "E. A. WILDE, - "Secretary to the Judge.

"To C. Knight Watson, Esq. " \&cc. \&c." 
“ Principal Registry, Court of Probate, "3rd May, 1865.

" My Lord,

"I have read the letters which you forwarded for my perusal from the Treasury, the Society of Antiquaries, and the Camden Society; and beg to say that in every communication I have had with the Treasury and the Office of Works respecting the necessary accommodation required for the Registry, I have steadily kept in view your Lordship's instructions to seize every opportunity that offered for providing further facilities for literary investigations, As I cannot, however, reconcile the extending even the privileges at present enjoyed by literary inquirers in London to the District Registries, so long as they remain under their present regulations, with the duties which I conceive devolve on the officers of the Court of Probate, as custodians of probably the most valuable legal documents in the kingdom, I have thought it better to draw up a detailed report, which I send herewith. Should your Lordship concur in my views, and the Liords of the Treasury consent to carry them out, I have every hope that at the end of no great length of time not only literary applicants, but the public generally, will have the fullest access to our Records which, in my opinion, will be consistent with our duties as their guardians.

"I have the honour to be,

"My Lord,

" Your Lordship's obedient servant,

(Signed) "A. F. BAYFoRD,

"To Rt. Honble. Sir J. Wilde."

"Senior Registrar.

The Council in acknowledging these Letters expressed to the Society of Antiquaries their satisfaction at receiving this assurance of Sir James Wilde's anxiety to promote the full use of the Wills and Records under his Lordship's charge; and their readiness to concur with the Society of Antiquaries in addressing Parliament or the Lords of the Treasury on the subject, should any such course be deemed useful or desirable.

The Council have reason to believe that since the close of this correspondence the same subject has been mooted in another and highly influential quarter, and with some expectations of beneficial results.

By order of the Council,

18th April, 1866.

John Bruce, Director.

William J. Thoms, Secretary. 


\section{REPORT OF THE AUDITORS.}

We, the Auditors appointed to audit the Accounts of the Camden Society, report to the Society, that the Treasurer has exhibited to us an account of the Receipts and Expenditure from the 15th of April, 1865, to the 15th of April, 1866, and that we have examined the said accounts, with the vouchers relating thereto, and find the same to be correct and satisfactory.

And we further report that the following is an Abstract of the Receipts and Expenditure during the period we have mentioned.

Recerpts. $\quad$ s. $d$.

To Balance of last year's account. . 429 if 5

Received on account of Members whose Subscriptions were in arrear at last Audit .............

Thelike on account of Subscriptions due on the lat of May, $1865 \ldots$...

The like on account of Subscriptions due on the 1st of May, 1866....

One year's dividend on $£ 101631$ 3 per Cent. Consols, standing in the names of the Trustees of the Society, deducting Income Tax..

To Sale of the Publications of past years to Members of the Society

To Sale of Promptorium Parvulorum (3 vols, in 1) .............. To one Composition in lieu of Annual Subscription ..........
Expendituri.

Paid for printing 750 copies, No. 89, Promptorium Parvulorum, Tom. III. .................... Paíd for reprinting 250 copies Promptorium Parvulorum, Tom. I.

Paid for Lithographing facsimile for ditto ......... 3 . 5 . 0

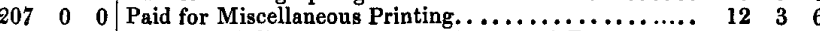

Paid for delivery and transmission of Books, with

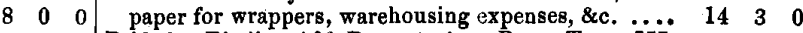

Paid for Binding 500 Promptorium Parv. Tom. III., 250 Promptorium Parv. Tom. I. II. III. (Roxburghe), and for 25 each of Nos. 59, 72, and 74... 50 i7 0

$29 \quad 19 \quad 8$ Paid for Insurance.......................... 1

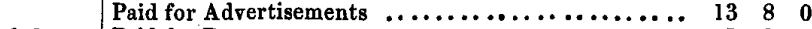

16150 Pajd for Paper........................... $45 \quad 810$

42170 Paid for postages, carriage of parcels, and other petty cash expenses........................ 6 6 $0^{7}$

$10 \quad 0 \quad 0$ Paid for printing 600 copies of Relations between Eng-

land and Germany .................... $73 \quad 9 \quad 6$

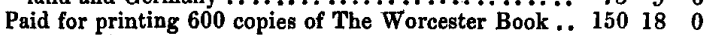

By Balance............ $178 \quad 11 \quad 7$

$£ 767 \quad 6 \quad 1$

And we, the Auditors, further state, that the Treasurer has reported to us, that over and above the present balance of $£ 178$ 11s.7d. there are outstanding various subscriptions of Foreign Members, and of Members resident at a distance from London, which the Treasurer sees no reason to doubt will shortly be received.

Hen. Hill.

W. D. Hamilton. 